\title{
The Effects of Compost Sources and Dosage on the Growth and Yield of Edamame Soybean (Glycine Max (L.) Merr) in Ultisol
}

\author{
Mentari Rizki Andriani ${ }^{1}$, Hesti Pujiwati ${ }^{2}$, Nanik Setyowati ${ }^{2}$
}

\author{
${ }^{1}$ Agroecotechnology Study Program, Faculty of Agriculture, University of Bengkulu, Indonesia. \\ ${ }^{2}$ Department of Crop Production, Faculty of Agriculture, University of Bengkulu, Indonesia. \\ Email: mentari.ra@gmail.com
}

\begin{abstract}
Use of marginal land use, such as Ultisol is an alternative for the extensification of soybean production. The problem of Ultisol is the low organic matter content, so fertilization is required using organic fertilizer such as compost. This study was designed to determine the effect of the compost source and its dosage on the growth and yield of Edamame soybean. The study was carried out in Pematang Gubernur Village, Muara Bangkahulu District, Bengkulu City, from February to June 2020 in Ultisol. The experiment was arranged using Randomized Complete Block Design (RCBD), with three replications. The first factor was the source of compost consisting of Wedelia (Wedelia trilobata L.), Siam weed (Chromolaena odorata L.), and Calopo (Calopogonium mucunoides). The second factor was the dosage, consist of 5, 10, and 15 tons ha ${ }^{-1}$ of the compost. No fertilization for control. There was no significant difference between Wedelia, Siam weed, and Calopo compost on the growth and yield of Edamame soybean. However, compost dosage resulted in significant differences in stem diameter, number of leaves, number of productive branches, and root dry weight. The dose of compost affects soybean growth, including stem diameter, number of leaves, number of productive branches, and dry root weight. Each increase in the compost dosage unit can increase $0.0707 \mathrm{~mm}$ stem diameter, 0.0896 leaves, 0.097 productive branches, and $0.1126 \mathrm{~g}$ dry root weight.
\end{abstract}

Keywords: compost source, dosage compost, Edamame, soybean, Ultisol

\section{INTRODUCTION}

Edamame soybean (Glycine $\max (\mathrm{L})$. Merr) is a green vegetable or green soybean vegetable which is important in Japan, Taiwan, China, and Korea. According to Widati and Hidayat [1] edamame soybeans contain protein, calcium, iron, vitamins A, $\mathrm{B} 1$, and $\mathrm{C}$, as well as potassium, ascorbic acid, and vitamin E with a nutrient content of $40 \%$ protein, $20 \%$ fat (without cholesterol.), 33\% carbohydrates, and 6\% fiber (by dry weight). Muaris [2] said besides that edamame soybeans contain antioxidants and isoflavones which are good for health. Kartahadimaja et al. [3] assume that edamame soybeans are almost the same as regular soybeans, except that the plant size is bigger and the seeds are black, green, or yellow.

Balitkabi [4] reported that the demand for the export market is still relatively large, especially from Japan, but there is only 1 company producing and exporting edamame soybeans. High market demand is certainly a good prospect for edamame soybeans, so there is a need for increased production. In addition to a climate that is suitable for the growth of edamame soybeans, there should also be efforts to increase production by adding organic matter, especially on marginal lands such as ultisol.

Ultisol is a soil with a high level of washing and low fertility. Hakim [5] said that ultisol soils are found in wet tropics, and cover about $8.1 \%$ of the land that supports the world's population. Marginal land use is due to the narrowing of fertile land for agriculture, so that marginal land use such as ultisols is an option. According to Prasetyo and Suriadikarta [6], one of the obstacles of ultisol soil is its low organic matter content, making it necessary to manage the organic matter. The organic material in question can be in the form of compost, which is useful for improving the physical, biological, and chemical properties of the soil; it can also be a source of nutrients for plants.

Compost or composting can be defined as the process of decomposing compounds contained in the remaining organic material to make it easily utilized by Djaja plants [7]. The decomposition process in compost is usually assisted by certain microorganisms, which will break down the content in organic matter. Therefore, the selection of organic material to be composted is important. The organic material used is generally high in nitrogen $(\mathrm{N})$ content. Organic materials in nature that have a high $\mathrm{N}$ content include wedelia (Wedelia trilobata), siam weed (Chromolaena odorata), and legume cover crop (LCC) of the type Calopogonium mucunoides. Wedelia is a wild plant and often becomes a weed for plants on cultivated land. The use of Wedelia as raw material for organic fertilizers has been widespread, both in the form of liquid fertilizer and compost. Based on the research results of Setyowati et al. [8] the use of 23 tons/ha of compost compost yields better mustard plant yields 
compared to the use of urea fertilizers doses of 160 tons/ha

Siam weed is also one of the wild plants in cultivated land and has now received attention as a raw material for organic fertilizer. Siam weed has a high nutrient content such as N $2.56 \%$, P $0.38 \%$, K $2.41 \%$, and $\mathrm{C} / \mathrm{N}$ below the critical point, this allows siam weed compost to easily and quickly mineralize Nugroho et al. [9]. According to Subaedah [10], giving organic matter siam weed and Crotalaria juncea which is then accompanied by $\mathrm{P}$ fertilizer can increase $\mathrm{P}$ uptake, plant relative growth rate, and biomass of soybean plants. Another study said the yield was 1.5 tons/ha due to the provision of 30 tons/ha of siam weed compost according to a report by Kastono [11].

Meanwhile, Calopogonium mucunoides (calopo) is a type of legume cover crop (LCC) which is commonly used in plantation areas, especially rubber. However, this plant is also often found growing wild in certain areas so that it is easy to find and obtain. According to its family, namely leguminoceae, this plant can bind $\mathrm{N}$ from the air with the help of Rhizobium bacteria, so that calopo has a high $\mathrm{N}$ content Purwanto [12]. The amount of calopo nutrient content includes $\mathrm{N} 3.47 \%$, P $0.18 \%$, K $1.79 \%$, Ca $0.73 \%$ and $\mathrm{Mg} 0.22 \%$ ICRI [13]. Soybean plants that were given a calopo compost of 2.5 tons/ha to produce a percentage of pithy pods, the number of seeds planted and the weight of 100 seeds which were higher than artificial fertilizers Khodijah and Rasyad [14].

Based on the description above, the addition of organic fertilizer in the form of compost from the three ingredients can increase the nutrient content in ultisols. Besides, the addition of compost can also increase the fertility of ultisols. So it is necessary to find the right dose to get the potential edamame soybean results in ultisols.

\section{MATERIAL AND METHOD}

\subsection{Experimental Design and Treatment}

The design of this study used a factorial completely randomized block design (RAKL) with 2 treatment factors, namely the type of compost and the dose of compost. The first factor is the type of compost, which consists of $\mathrm{J} 1=$ wedelia, $\mathrm{J} 2=$ siam weed and $\mathrm{J} 3=$ calopo. The second factor was the dosage of compost which was D1 $=5$ tons $/$ ha, D2 $=10$ tons $/$ ha, D3 $=15$ tons / ha and Control = without giving compost, as a comparison. Thus obtained 9 treatment combinations and 1 control

$$
\begin{aligned}
& \mathrm{J} 1 \mathrm{D} 1=\text { wedelia } 22 \mathrm{~g} \\
& \mathrm{~J} 1 \mathrm{D} 2=\text { wedelia } 44 \mathrm{~g} \mathrm{~J} \text { 1D3 = wedelia } 66 \mathrm{~g} \mathrm{~J} \text { D1 }= \\
& \text { siam weed } 22 \mathrm{~g} \mathrm{~J} \text { 2D2 = siam weed } 44 \mathrm{~g} \mathrm{~J} \text { 2 } 3= \\
& \text { siam weed } 66 \mathrm{~g} \mathrm{~J} \text { 3D1 = calopo } 22 \mathrm{~g} \mathrm{~J} 3 \mathrm{D} 2= \\
& \text { calopo } 44 \mathrm{~g} \mathrm{~J} \text { 3D3 = calopo } 66 \mathrm{~g} \\
& \text { Control = without compost }
\end{aligned}
$$

Each treatment was repeated 3 times. For each treatment, there were 3 polybags so that 90 polybags were obtained.
The data obtained were analysed statistically by using the Analysis of Variance (ANOVA) at 5\% level The ANOVA results showed a significant effect on the dose of fertilizer, then continued with the Orthogonal Polynomial (PO) at linear levels.

\subsection{Composting Procedure}

Composting begins with cultivating bacteria, by mixing $1 \mathrm{~L}$ EM-4 and $2 \mathrm{~L}$ of water. The mixture is allowed to stand for 1 week until the bacteria multiply. Then, $10 \mathrm{~kg}$ of condensed plant biomass is cut to the size of $2-3 \mathrm{~cm}$. Then $120 \mathrm{ml}$ of bacterial culture dissolved in $2 \mathrm{~L}$ of water is added. Next, the compost material and bacteria solution is mixed until evenly distributed. The compost material is then put into a large plastic bag and stored for 1 month. Every week the compost material is stirred and the temperature is low. This also applies to Siamese weeds and brokers.

\subsection{Grow Media Preparation}

The land used is ultisol land from in Pematang Gubernur Village, Muara Bangkahulu District, Bengkulu City. Soil is taken from the top soil to a depth of $20-30 \mathrm{~cm}$, then the soil is dried in the sun and sieved. Furthermore, the soil is put into a polybag measuring $30 \times 40 \mathrm{~cm}$ as much as $10 \mathrm{~kg}$. Then the planting medium is given compost according to the treatment.

\subsection{Edamame Soy Cultivation}

Edamame soybeans are planted after 1 week of compost application on the planting medium. Edamame seeds were previously given Rhizobium sp. Each polybag was planted 2 seeds and given an insecticide with the active ingredient Karbofuran. Basic fertilization is carried out 1 week after planting which includes urea and $\mathrm{KCl}$, for TSP given at planting. Every morning or evening the edamame soybeans are watered. Control of plant pests is carried out mechanically and chemically. Edamame plants are harvested after 65 days. The variables observed were plant height, stem diameter, number of leaves, flowering age, number of branches per plant, number of productive branches per plant, root stover dry weight, crown stover dry weight, number of pods per plant, number of empty pods per plant, number of pods. contains per plant, pod weight per plant, percentage of pods filled, weight of root nodules, number of root nodules per plant, number of effective nodules per plant.

\section{RESULT AND DISCUSSIONS}

\subsection{Analysis of Variance}

The results of observations in the field were then analyzed using ANOVA. ANOVA results showed that the interaction between the type and dose of compost did not affect the growth and yield of edamame soybeans. The single factor type of compost also has no effect. Only the compost dosage factor showed an effect on the growth of edamame soybeans (Table 1.) 
Table 1. Summary of analysis of variance

\begin{tabular}{|c|c|c|c|c|}
\hline \multirow{2}{*}{ Variable } & \multicolumn{4}{|c|}{ F Count } \\
\hline & Type & Dose & Interaction & $\mathrm{KK}(\%)$ \\
\hline Plant height & $0.08 \mathrm{~ns}$ & $0.53 \mathrm{~ns}$ & $0.32 \mathrm{~ns}$ & 10.86 \\
\hline Stem diameter & $2.17 \mathrm{~ns}$ & $6.19 * *$ & $1.30 \mathrm{~ns}$ & 12.59 \\
\hline Number of leaves & $0.13 \mathrm{~ns}$ & $4.02 *$ & $0.87 \mathrm{~ns}$ & 14.27 \\
\hline Flowering age & $1.27 \mathrm{~ns}$ & $0.27 \mathrm{~ns}$ & $1.41 \mathrm{~ns}$ & 8.89 \\
\hline Number branches of plan & $1.44 \mathrm{~ns}$ & $3.06 \mathrm{~ns}$ & $0.89 \mathrm{~ns}$ & 19.41 \\
\hline Number of productive branches & $1.13 \mathrm{~ns}$ & $3.58 *$ & $0.58 \mathrm{~ns}$ & 20.41 \\
\hline Dry root weight & $0.14 \mathrm{~ns}$ & $4.42 *$ & $2.70 \mathrm{~ns}$ & 26.38 \\
\hline Dry canopy weight $^{\mathrm{T}}$ & $0.01 \mathrm{~ns}$ & $2.37 \mathrm{~ns}$ & $0.71 \mathrm{~ns}$ & 17.78 \\
\hline Number pod of plant & $1.21 \mathrm{~ns}$ & $2.80 \mathrm{~ns}$ & $0.35 \mathrm{~ns}$ & 22.28 \\
\hline Number empty pod of plant & $0.38 \mathrm{~ns}$ & $0.76 \mathrm{~ns}$ & $2.44 \mathrm{~ns}$ & 18.25 \\
\hline Number pithy pod of plant & $0.23 \mathrm{~ns}$ & $0.71 \mathrm{~ns}$ & $2.00 \mathrm{~ns}$ & 5.62 \\
\hline Pod weight of plant & $0.02 \mathrm{~ns}$ & $1.16 \mathrm{~ns}$ & $0.46 \mathrm{~ns}$ & 23.33 \\
\hline Percentage pithy pod & $0.23 \mathrm{~ns}$ & $0.71 \mathrm{~ns}$ & $2.00 \mathrm{~ns}$ & 5.62 \\
\hline Root nodules weight $^{\mathrm{T}}$ & $1.19 \mathrm{~ns}$ & $1.72 \mathrm{~ns}$ & $0.12 \mathrm{~ns}$ & 15.00 \\
\hline Number root nodules of plant ${ }^{\mathrm{T}}$ & $0.31 \mathrm{~ns}$ & $1.54 \mathrm{~ns}$ & $0.16 \mathrm{~ns}$ & 38.82 \\
\hline Number effective root nodules ${ }^{\mathrm{TT}}$ & $1.17 \mathrm{~ns}$ & $1.68 \mathrm{~ns}$ & $0.11 \mathrm{~ns}$ & 9.21 \\
\hline
\end{tabular}

$*$ = Significantly different, $* *=$ Very significant difference, $\mathrm{ns}=$ not significantly different $\mathrm{T}=$ transformation data $\sqrt{ }(\mathrm{x}+1) \mathrm{TT}=$ transformation data $\sqrt{ }(\mathrm{x}+2)$

\subsection{Effects of Compost Type on Growth and Yield of Edamame}

The three types of compost used did not show any differences or different effects on the growth and yield of edamame soybeans. This is because the nutrient content of the three types of compost is not much different. The content of the wedelia was $\mathrm{N}$ $2.52 \%, \mathrm{P} 0.63 \%$, K $1.03 \%$, C-organic $13.469 \%$, and KA $31.83 \%$. The content of siam weed was $\mathrm{N}$ $3.08 \%$, P $0.81 \%$, K $1.09 \%$, C-organic $14.243 \%$, and KA $25.93 \%$. While the content of calopo is $\mathrm{N} 2.80 \%$, $\mathrm{P} 0.55 \%, \mathrm{~K} 0.90 \%$, C- organic $13.469 \%$ and KA $18.75 \%$. So this makes the effect or effect of the type of compost not visible on the growth and yield of edamame soybeans. However, the nutrient content in the compost used is classified as moderate to high, such as the minimum content of $\mathrm{N} 0.40 \%, \mathrm{P} 0.10 \%$, $\mathrm{K} 0.20 \%$, C $9.80 \%$ - 32\%, maximum KA $50 \%$ (Standardization Body National (BSN), 2004). The observations on the growth of edamame soybeans due to the application of siam weed compost gave the highest yields for almost all growth variables except crown dry stover weight (Table 2). While the effect of the type of compost on edamame soybean yields gave the best results for pod variables was siam weed compost, but for root nodule variables the highest was calopo (Table 3).

Table 2. Effect of compost types on the growth of edamame soybeans

\begin{tabular}{|l|l|l|l|l|l|l|l|l|}
\hline \multirow{2}{*}{$\begin{array}{c}\text { Type of fertilizer } \\
\text { (ton/ha) }\end{array}$} & \multicolumn{2}{l|}{ Variable } \\
\cline { 2 - 11 } & PH & SD & NL & FA & NB & NPB & DRW & DCW \\
\hline Wedelia & 28.21 & 6.00 & 8.41 & 4.78 & 4.67 & 4.59 & 4.65 & 11.78 \\
\hline Siam weed & 28.31 & 5.56 & 8.70 & 4.96 & 5.37 & 5.22 & 4.93 & 11.12 \\
\hline Calopo & 27.76 & 5.33 & 8.52 & 5.11 & 4.78 & 4.67 & 4.94 & 7.22 \\
\hline control & 26.78 & 5.13 & 7.44 & 5.22 & 4.11 & 4.00 & 4.04 & 5.67 \\
\hline & & & & & & & & \\
\hline
\end{tabular}

$\mathrm{PH}=$ Plant height, $\mathrm{SD}=$ Stem diameter, $\mathrm{NL}=$ Number of leaves, $\mathrm{FA}=$ Flowering age, $\mathrm{NB}=$ Number branches of plan, NPB = Number productive branches of plant, DRW = Dry root weight, DCW =Dry canopy weight 
Table 3. Effect of compost types on edamame soybean yield

\begin{tabular}{|c|c|c|c|c|c|c|c|c|}
\hline \multirow{2}{*}{$\begin{array}{l}\text { Type of fertilizer } \\
\text { (ton/ha) }\end{array}$} & \multicolumn{8}{|c|}{ Variable } \\
\hline & $\mathrm{NP}$ & NEP & NPP & $\mathrm{PW}$ & PPP & RNW & NRN & NERN \\
\hline Wedelia & 25.11 & 1.52 & 23.59 & 60.52 & 93.35 & 0.35 & 4.59 & 3.81 \\
\hline Siam weed & 63.33 & 1.78 & 25.04 & 59.74 & 92.08 & 0.56 & 5.22 & 4.30 \\
\hline Calopo & 22.89 & 1.41 & 21.48 & 59.11 & 93.67 & 0.70 & 6.89 & 6.07 \\
\hline control & 18.33 & 0.78 & 17.56 & 41.78 & 94.89 & 0.23 & 3.33 & 2.69 \\
\hline
\end{tabular}

$\mathrm{NP}=$ Number pod of plant, NEP = Number empty pod of plant, NPP = Number pithy pod of plant, $\mathrm{PW}=$ Percentage pithy

pod, $\mathrm{PPP}=$ Percentage pithy pod, RNW = Root nodules weight, NRN = Number root nodules of plant, NERN $=$ Number effective root nodules

\subsection{Effect of Compost Dosage on Edamame Growth and Yield}

Compost application to edamame showed significantly different results. The different results were shown by the observation variables of stem diameter, number of leaves, number of productive branches per plant, and dry weight of root stover. The table of observations on the dosing factors can be seen in Tables 4 and 5 .

Table 4. Effect of compost dosage on the growth of edamame soybeans

\begin{tabular}{|l|l|l|l|l|l|l|l|l|}
\hline $\begin{array}{l}\text { Fertilizer dosage } \\
\text { (ton/ha) }\end{array}$ & Variable \\
\hline & PH & SD & NL & FA & NB & NPB & DRW & DCW \\
\hline 0 & 26.78 & $5.13^{* *}$ & $7.44^{*}$ & 5.22 & 4.11 & $4.00^{*}$ & $4.04^{*}$ & 5.67 \\
\hline 5 & 27.32 & $4.96^{* *}$ & $7.81^{*}$ & 4.89 & 4.33 & $4.15^{*}$ & $4.03^{*}$ & 9.12 \\
\hline 10 & 28.80 & $5.95^{* *}$ & $9.41^{*}$ & 4.93 & 5.07 & $5.00^{*}$ & $4.71^{*}$ & 11.08 \\
\hline 15 & 28.16 & $5.98^{* *}$ & $6.26^{*}$ & 5.04 & 5.41 & $5.33^{*}$ & $5.78^{*}$ & 13.63 \\
\hline
\end{tabular}

$\mathrm{PH}=$ Plant height, $\mathrm{SD}=$ Stem diameter, $\mathrm{NL}=$ Number of leaves, $\mathrm{FA}=$ Flowering age, $\mathrm{NB}=$ Number branches of plan, NPB = Number productive branches of plant, DRW = Dry root weight, DCW =Dry canopy weight

Table 5. Effect of dosage of kopos fertilizer on edamame soybean yield

\begin{tabular}{|l|l|l|l|l|l|l|l|l|}
\hline $\begin{array}{l}\text { Fertilizer dosage } \\
\text { (ton/ha) }\end{array}$ & \multicolumn{9}{l|}{ Variable } \\
\hline & NP & NEP & NPP & PW & PPP & RNW & NRN & NERN \\
\hline 0 & 18.33 & 0.78 & 17.56 & 41.78 & 94.89 & 0.23 & 3.33 & 2.69 \\
\hline 5 & 22.00 & 1.30 & 20.70 & 54.19 & 94.29 & 0.33 & 3.56 & 3.11 \\
\hline 10 & 28.04 & 1.22 & 26.15 & 62.85 & 91.39 & 0.53 & 5.52 & 4.41 \\
\hline 15 & 24.81 & 1.52 & 23.26 & 62.33 & 93.42 & 0.47 & 4.85 & 4.33 \\
\hline
\end{tabular}

$\mathrm{NP}=$ Number pod of plant, NEP $=$ Number empty pod of plant, NPP = Number pithy pod of plant, $\mathrm{PW}=$

Percentage pithy pod, PPP = Percentage pithy pod, RNW = Root nodules weight, NRN = Number root nodules of plant, NERN $=$ Number effective root nodule 
The dose of compost affects stem diameter, number of leaves, number of productive branches, and dry weight of edamame soybean root stover and forms an Orthogonal Polynomial graph as follows.

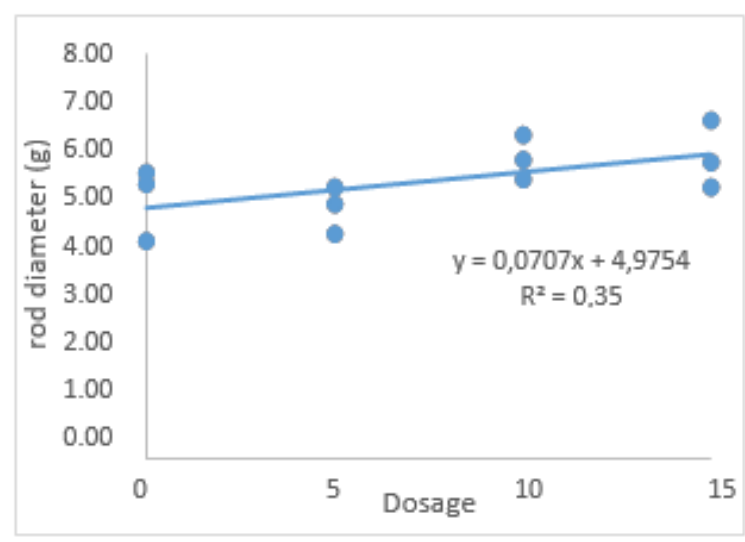

Figure 1. Effect of dose on stem diameter

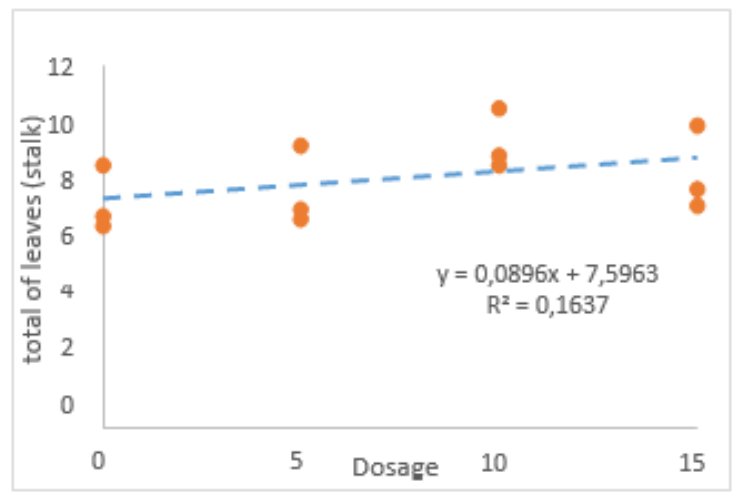

Figure 2. Effect of Fertilizer dosage on number of leaves

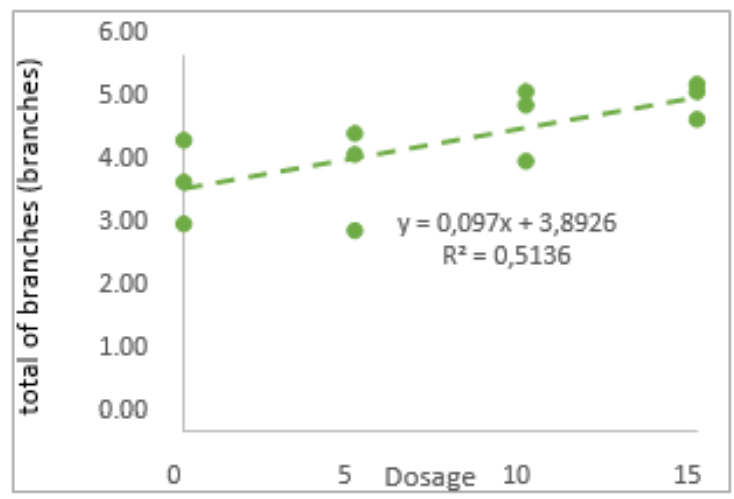

Figure 3. Effect of Fertilizer dosage on the number of productive branches

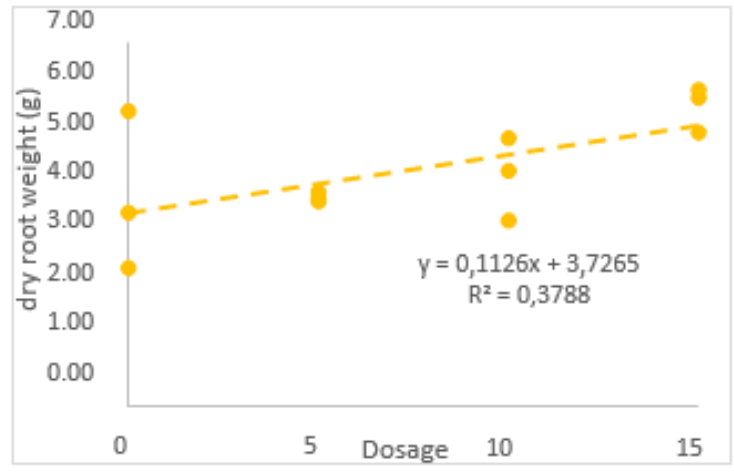

Figure 4. Effect of dose on dry root weigh

\section{Stem Diameter}

The PO test results (Figure 2) show that the stem diameter response to compost dosage follows a linear pattern with $\mathrm{Y}=0.0707 \mathrm{x}+4.9754$ with a coefficient of determination $\mathrm{R} 2=0.35$. This equation means that each additional compost dose unit can increase the stem diameter by $0.0707 \mathrm{~mm}$. Based on field observations, the largest stem diameter was given a fertilizer dose of 15 tons/ha with a stem diameter of $5.98 \mathrm{~mm}$. Whereas in giving a fertilizer dose of 10 tons/ha the stem diameter was $5.95 \mathrm{~mm}$ (Table 4.). The nutrient content in the fertilizer greatly affects the dosage requirements of the fertilizer to be used. The higher the nutrient content in the fertilizer, the less fertilizer is needed, and vice versa. In addition, the number of fertilizer doses is not always good, from the observation that the fertilizer dose of 10 tons/ha is more effective than the fertilizer dose of 15 tons/ha. In accordance with the report of Nursyabani et al. [15] administration of a dose of $7.5 \%(\mathrm{w} / \mathrm{w}$ ) increases the rate of hydrocarbon degradation by $0.18 \%$ / week while the $5 \%(\mathrm{w} / \mathrm{w})$ dose increases $0.15 \%$ / week, but the analysis results show that the dose of $5 \%(\mathrm{w} / \mathrm{w})$

$\%$ is the best dose.

\section{Number of Leaves}

The PO test results on the number of leaves due to compost dosing, formed a linear pattern with $\mathrm{Y}$ $=0.0896 \mathrm{x}+7.5963$ with a dermination coefficient $\mathrm{R} 2$ $=0.637$ (Figure 3.). this means that each additional unit dose of compost tends to increase the number of leaves as much as 0.0896 . The most leaf yields in field observations were given a fertilizer dose of 10 tonnes / ha which could produce an average of 9 leaves. A fertilizer dose of 15 tonnes / ha produced fewer leaves on average, namely 6 pieces (Table 4.). Giving high doses of fertilizer can actually reduce the average number of leaves. This is the same as the report of Safuf et al. [16] giving a dosage of $75 \mathrm{~g} /$ plant compost yields an average leaf rate of 4.8 leaves, but at a dose of $100 \mathrm{~g}$ / plant the average leaves decreased to 4.0 leaves.

\section{Number of Productive Branches}

PO analysis in Figure 4. Shows a linear pattern that forms the equation $\mathrm{Y}=0.097 \mathrm{x}+3.8926$ 
with the coefficient of determination $\mathrm{R} 2=0.5136$. This equation means that each increase in the unit dose from a dose of 5 tons/ha - 15 tons/ha is able to increase the number of productive branches by an average of 0.097 branches. Giving compost dosage of 15 tons/ha was able to produce an average productive branch of 5.33 branches. These results are not much different from the administration of a dose of 10 tons/ha which is able to produce an average of 5 productive branches. So it can be said that the dose of 10 tons/ha is more effective in increasing the number of productive branches.

\section{Dry Root Weight}

Furthermore, from the graph in Figure 5 , it is found that $Y=0.1126 x+3.7265$ and the coefficient of determination $\mathrm{R} 2=0.37$. This equation means that each increase in the unit dose of manure will increase the dry weight of root stover by $0.1126 \mathrm{~g}$. Giving a dose of 15 tons/ha can increase the highest root dry stover weight, namely an average of $5.78 \mathrm{~g}$ (Table 4.). However, at a dose of 10 tons/ha it was able to increase the root stover weight by $4.71 \mathrm{~g}$ on average (Table 4.). So that at a dose of 10 tons/ha it is sufficient. This opinion is in line with the cultivation guidelines of Soewanto et al. [17] who add 10-20 m3 / ha or the equivalent of 10-20 tons/ha of manure.

\section{CONCLUSIONS}

Based on the results of research and analysis, the following conclusions were obtained:

1. There were no interactions between dosage and compost types on the growth and yield of edamame soybeans.

2. The types of compost have no significant effect on the growth and yield of edamame soybeans.

3. The dose of compost has an effect on soybean growth, including stem diameter, number of leaves, number of productive branches, and dry root weight. Each increase in the compost dosage unit can increase $0.0707 \mathrm{~mm}$ stem diameter, 0.0896 leaves, 0.097 productive branches, and $0.1126 \mathrm{~g}$ dry root weight.

\section{REFERENCES}

[1] Widati, F, Hidayat IM. Kedelai sayur (Glycine ma L. Merril) sebagai tanaman pekarangan. Balai Penelitian Tanaman Sayur. Iptek Hortikultura, 2012 Nov;(8):25-8.

[2] Muaris H. Khasiat Edamame untuk Kestabilan Kesehatan: Fakta Gizi Edamame dan Manfaat untuk Kesehatan. Jakarta: PT Gramedia Pustaka Utama; 2014. 7 p

[3] Kartahadimaja J, Wentasari R, Sesanti RN. Pertumbuhan dan produksi polong segar edamame varietas rioko pada empat type of fertilizer. Jurnal Agrovigor, 2010 Sep; 3(2): 1316.

[4] Balai Penelitian Tanaman Aneka Kacang dan Umbi. Berita: Kedelai Sayur Edamame. Available from URL: http://balitkabi.litbang.pertanian.go.id/berita/ked elai- sayur-edamame/. 2018.

[5] Hakim DL. Ensiklopedia Jenis Tanah di Dunia. Ponorogo: Uwais Inspirasi Indonesia: 2019. 43 p

[6] Prasetyo B H, Suriadikarta DA. Karakteristik, potensi, dan teknologi pengelolaan tanah ultisol untuk pengembangan pertanian lahan kering di Indonesia. Jurnal Litbang Pertanian, 2006; 25(2): 39-46.

[7] Djaja W. Langkah Jitu Membuat Kompos dari Kotoran Ternak \& Sampah. Tangerang: Agromedia Pustaka: 2008. 8 p

[8] Setyowati N, Nurjanah U, Haryanti D. Gulma tusuk konde (Wedelia trilobata) dan kirinyu (Chromolaena odorata) sebagai pupuk organik pada sawi (Brassica chinensis L.). Jurnal Akta Agrosia, 2008; 11(1): 47-56.

[9] Nugroho B, Mildaryani W, Dewi SHC. Potensi gulma siam (Chromolaena odorata L.) sebagai bahan kompos untuk pengembangan bawang merah organik. J. Agron,2019 Aug 47(2): 180-7.

[10] Subaedah St. Peran bahan organi Chromolaena odorata dan Crotalaria juncea dalam meningkatkan ketersediaan hara fosfor bagi pertumbuhan tanaman kedelai di lahan kering. Jurnal Agrotek, 2017 Sep 2; 1(2): 63-74.

[11] Kastono D. Tanggapan pertumbuhan dan hasil kedelai hitam terhadap penggunaan pupuk organik dan biopestisida gulma siam (Chromolaena odorata). Ilmu Pertanian, 2015; 12 (2): 103-16

[12] Purwanto I. Mengenal Lebih Dekat Leguminoseae. Yogyakarta: Kanisius. 2011.21 p

[13] Balai Penelitian Tanah (Balittanah). Mengenal Calopogonium mucunoides sumber pupuk hijau dan bahan organik. Warta Penelitian dan Pengembangan Pertanian, 2010; 32(4): 9-10.

[14] Khodijah NN Rasyad A. Pengaruh pemberian kompos calopogonium mucunoides dan jarak tanam terhadap pertumbuhan dan hasil kedelai (Glycine max (L). Merril). JOM FAPERTA UR, 2018 Jan-Jul; 5(1)

[15] Nursyabani, DD, Suryatmana P, Sudiarja R. Pengaruh jenis inokulan dan dosis kompos dala fitoremediasi menggunakan tanaman rami. Jurnal Penelitian Saintek, 2020; 25(1): 84-94. DOI: https://doi.org/10.21831/jps.v25i1.20035.

[16] Safuf E, Thomas A, Rombang JA, Kalangi JI. Pengaruh pemberian pupuk kompos terhadap pertumbuhan bibit jabon merah (Anthocephalus macrophyllus). Jurnal Ilmiah Pertanian Universitas Sam Ratulangi, 2015; 6(17): 1-13.

[17] Soewanto, H., A. Prasongko dan Sumarno. Agribisnis edamame untuk ekspor. Available from URL: http://balitkabi.litbang.pertanian.go.id/wpcontent/uploads/2016/03/dele_18.hasni_.pdf. 2016. 